\title{
Halı ve Düz Dokuma Yaygllarla ilggili Araştırmaların Kazanımları, Sorunları Bunların Getirdiği Problemlerin Çözümüne Yönelik Bir Öneri
}

\section{The Contribution of Reasearh Concerning Carpets and Flat Weavings, the Problems Raising from the Results of Their Evaluations and a Proposal}

H. Örcün BARIŞTA*

\section{ÖZET}

Halı, kilim, cicim, sumak, zili vb. gibi isimlerle kirkitli dokumalar başlığı altında kümelenen iplik işlerinin (tekstil) Anadolu ve çevresinde gelişen Türk sanatında köklü bir geçişmişi ve zaman zaman güzel sanatlar düzeyine ulaşan örnekleri bulunmaktadır. Selçuklu Dönemi, Beylikler Dönemi ve Osmanlı İmparatorluğu Döneminden sonra Türkiye Cumhuriyeti Döneminde de süregelen, geleneksel bir sanat dalı olma niteliğini de taşıyan, bu engin sanat dalı üzerinde çeşitli ana bilim ve ana sanat dalları alanlarında yapılmış araştırmalar vardir. Ancak günümüze değin çok yol alınmış olduğu gözlenen kirkitli dokumalarla ilgili araştırmalar bazı problemlerin varlığına işaret etmektedir.

Bu bildiride amacımız çeşitli araştırma ve yayınlardan oluşan seçme kaynakçanın değerlendirilmesine dayanarak bir durum saptaması yapmak, bu dalda ulaşılan bilimsel ve sanatsal düzeye katkıda bulunmak, bu bağlamda metodolojiden kaynaklanan sorunları çözebilmek için bu alanda uygulanacak kayıt sisteminde kullanılacak envanter fişlerinden farklı olan gözlem fişlerine dikkat çekmek ve danışmanlığında yapılmış bazı tezlerin gözlem fişlerinin kazanımı olan bir halı gözlem fişi örneği sunmak ve bu yolla aynı gözlem fişi kullanarak bu alanda doğru ve kalıcı kayıt yapma yönünde bir öneri yapmaktır.

Anahtar Kelimeler: Dokuma Araştırma Yayın Problem Envanter fişi Gözlem fişi.
Prof. Dr., Marmara Üniversitesi Emekli Öğretim Üyesi, e-posta: orcunbarista@gmail.com

\section{ABSTRACT}

Weavings which are classified as kirkitli under the names of carpet, rug, cicim, sumak, zili. etc. have a deep historical background in Turkish art, which is developed in Anatolia and neighboring regions. Some weavings of these categories have reached the level of fine arts. This form of art has continued through Seljuk, Emirates, Ottoman, and republican periods. Although there are many researches concerning these artforms, there are some problems about the studies on kirkitli weavings.

The objective of this paper is to evoluate the bibliography involving various publications to contribute to the scientific level of this field, to emphasize the observation cards which are different from inventory cards and which are capable of solving methodological problems, and to propose an observation card format in order to find a correct and permanent basis for recording.

Keywords: Weavings, Research, Publication, Problem, Invertory Card, Observation Card.

\section{Halı ve Düz Dokuma Yaygıların Tanımı, Disiplinlerarası Konumu ve Önemi, Belgeleme Aşamasında Farklı Bakış Açıları lile Yapılmış Yayınlardan Kaynaklanan Sorunlarını Çözüme Yönelik Bir Öneri}

Halı, kilim, cicim, sumak, zili vb. gibi isimlerle kirkitli dokumalar başlığı altında kümelenen iplik işlerinin (tekstil) Anadolu ve çevresinde gelişen Türk sanatında köklü bir geçmişi ve zaman zaman güzel sanatlar düzeyine ulaşan örnekleri vardır. Selçuklu Dö- 
nemi, Beylikler Dönemi ve Osmanlı İmparatorluğu Döneminden sonra Türkiye Cumhuriyeti Döneminde de süregelen, geleneksel bir sanat türü olma niteliğini taşıyan, bu engin sanat dalı üzerinde üniversitelerin çeşitli ana bilim ve ana sanat dalları yanı sıra üniversiteler dışında kamu kurumları diğer kurumlar ve özel kişilerce yapılmış bazı araştırmalardan beslenen yayınlar bulunmaktadır. Bunlar bilim insanlarına, sanatçllara, sanatseverlere başvuru kaynakları oluşturmaktadır. Ancak günümüze değin çok yol alınmış olduğu gözlenen görsellerle desteklenmiş bu yazılı kaynaklar toplu bir değerlendirme amacı ile ele alındığı zaman bunların araştırmaya yönelik belgelenme aşamasında konuya farklı bakış açılarından kaynaklanan bazı problemleri olduğu gözlenmektedir. Kısaca kirkitli dokuma niteliğindeki kültür varlıklarının plastik sanatlar bağlamında belgelenmesi aşamasında beliren bu problemler:

- Kirkitli dokuma türleriyle motiflerin, kompozisyonların adlandırılmasındaki farklılıklar,

- Gereç ayrışımları başka deyişle analizleri bağlamında beliren boşluklar,

- Teknik çizimlerle fotoğraflarda başka deyişle görsellerde gözlenen eksiklikler,

- Yöntem farklılıklarıyla farklı bakış açılarından kaynaklanan kayıt sistemindeki farklılıklar,

- Üretilen yöre ve tarihlemede beliren sorunlar, olarak siralanabilir.

Bu bildiride amacımız bu dala ivme kazandıran bazı araştırmalar sonucu yapılmış yayınlara toplu bir bakış sonucunda belirlenen bazı problemlere eğilmek ve bu bağlamda bu alanda ulaşılan bilimsel ve sanatsal düzeye katkıda bulunmak, sorunları çözebilmek için araştırma yöntemleriyle ilgili bir öneri sunmaktır.

Bildiri çok sayıda çalışma bulunan bu alandaki bütün yayınları kapsamamaktadır. Başka deyişle çok geniş alana yayılan kaynaklar arasından örneklem bazı yayınlar dışında ağırlıklı olarak sanat tarihi disiplini alanında kaleme alınmış, seçme kitap, makale ve bildirilerle sınırlıdır. Seçme Kaynakça ünitesinde sıralanan çeşitli bakış açılarından bu alana katkı sağlayan bu yazılı kaynaklar üzerinde bir bildiri çerçevesinde ana çizgileriyle yapılan bir durum saptamasından sonra sunulan düşünceler bir öneriden oluşmaktadır. Öneri araştırmalara dayanan yayınlardan sağlanan yarar ve Barışta'nın danışmanlığında yapılmış lisans, yüksek lisans ve doktora tezlerindeki kazanımlara dayanarak hazırlanmış üzerinde tartışabilecek ve eklemeler yapılabilecek bir gözlem fişi ile örneklenmiştir. Bildiri Kirkitli Dokumalarla İlgili Seçme Kaynaklara Toplu Bir Bakış, Seçme Kaynaklardan Sağlanan Kazanımların Değerlendirilmesi Aşamasında Beliren Durumun Düşündürdükleri başlıkları altında kısaca şöyle özetlenebilir.

\section{Kirkitli Dokumalarla İlgili Seçme Kaynaklara Toplu Bir Bakış}

Bilindiği gibi halıcılıkla ilgili erken tarihli bir yayın Halıcılık Kongresi için İktisat Bakanlığınca yayımlanmış olan Dirik'in kitabıdır. ${ }^{.}$Onu Türkiye'de Halıcılık isimli halılarla ilgili genel bilgiler veren Kotan'ın kitabı izlemektedir. ${ }^{2}$ Belli bir zaman dilimi sonraya ait Türk halılarına da yer vermiş bir kitap Diez ve Aslanapa ${ }^{3}$ bir başka yabancı kaynak ise Doğu halıları arasında Selçuk, Erken Osmanlı ve Osmanlı başlıkları altında Anadolu ve çevresi Türk halılarına yer verilmiş olan Erdmann'ın kitabidır. ${ }^{4}$ Erdmann başka bir kitabı 15. Yüzyıl halılarını konu alan çalışmasıdır. ${ }^{5}$ Selçuklu Dönemine ait erken tarihli bir kitap Aslanapa- Durul', Selçuklu Dönemi halılarına yer verilmiş başka bir kitap $^{7}$ ile Beylikler Devrine ait bilgiler içeren başka bir kitap ${ }^{8}$ Öney'indir. Türk halı sanatına toplu bir bakışla eğilinmiş daha da başka bir kitap Aslanapa'nındır. ${ }^{9}$

Bu arada Kültür ve Turizm Bakanlı $\breve{g}^{10}$, TBMM Milli Saraylar ${ }^{11}$, Vakıflar Genel Müdürlüğüne bağlı bazı müze ${ }^{12}$ yayınlarında, Kültür ve Turizm Bakanlığının sergi kataloglarında ${ }^{13}$ ve bazı yurt dışındaki kiliselerle ${ }^{14}$ müzelere yapmış olduğu yayınlarda da halılara yer verilmiş olduğu görülmektedir. Dogu halıları arasında Uşak, Gördes, Ladik, Bergama vb. örneklerle Anadolu örnekleri bulunan

1 Kazım Dirik, Eski ve Yeni Türk Halıcılı̆ı, İstanbul, 1938.

2 Vasfi Kotan, Türkiye'de Halıcllı, İstanbul Ticaret ve Sanayi Odası, İstanbul, 1949

3 Ernst Diez- Oktay Aslanapa, Türk Sanatı, İstanbul Üniversitesi Edebiyat Fakültesi Yayınları, No 627, İstanbul.

4 Kurt Erdmann, Oriental Carpets, The Crosby Press, 1976, s. 17-23, 23-29,47-56.

5 Kurt Erdmann, Der Türkıshe Teppische Des 15. Jahrhunderts-15. Yüzyıl Türk Halısı, İstanbul Edebiyat Fakültesi Yayınları:715, Maarif Basımevi,Türkçe Metnin Redaksiyonu S. Ögel.

6 Oktay Aslanapa- Yusuf, Durul, Selçuklu Halıları, Ak Yayınları, Akbank.

7 Gönül Öney-Ü. Erginsoy, Anadolu Mimarisinde Süsleme ve El Sanatları, Türkiye İş Bankası, Kültür Yayınları, Genel Yayın No: 185, Sanat Dizisi:33, Ankara, 1978, 125-132.

8 Gönül Öney, Beylikler Devri Sanatı, XIV-XV. Yüzyıl, 1300-1453, Atatürk Kültür, Dil Ve Tarih Yüksek Kurumu, Ankara, 1989, s.51-54.

9 Oktay Aslanapa, Türk Halı Sanatının Bin Yilı, Eren, 1987.

10 Türk ve İlam Eserleri Müzesi, Akbank, 2002, s.276-279,310-313.

11 Ayşe Fazlıoğlu, Dügü̈mün Son Halkası; Osmanlı Sarayı Halılarl (Last Loop of The Knot; Ottoman Palace Carpets, Translition: Çiğdem Aksoy Fromm, TBMM, Milli Saraylar, 2007.

12 Suzan Bayraktar- Serpil, Özçelik, Halı Müzesi Ile Kilim Ve Düz Dokuma Yaygılar Müzesi Kataloğu, T.C.Vakıflar Genel Müdürlüğü, Ankara 2007.

13 Nazan Tapan, Hicretin 15. Yüzylında İslam Sanatları Sergisi,- İslamda Halı Sanat - On The Occasion Of The Fifteenth Centennial of Hegira Islamic Art Exhibition-Carpets In İslam, Ministry Of Culture And Tourism, İstanbul, 1983 Nazan Ölçer- Enderlein, Volkman- Frenc, Batari-John, Mills- Nils, Ruters, Turkish Carpet From The 13th-18th Centuries, Textilbank, Ertuğ, 1996

14 Micheal Fransis, "Transilvanya Kiliselerindeki Osmanlı Halıları, Katalog", Tanrı'ya Atanmış Halılar Transilvanya Kiliselerinde Anadolu Halıları 1500-1750, Sakıp Sabancı Müzesi, 2007. 
Macaristan'daki Estegong ${ }^{15}$ ve Budapeşte müzelerinden ${ }^{16}$ Rusya müzelerinden ${ }^{17}$ örnekler veren kitaplar ile Türk halı sanatı ${ }^{18}$ ile Türk halı ${ }^{19}$ ve Türk halı ve düz dokumaların Türk dünyası bağlantısıyla konu olarak alan ${ }^{20}$ kitaplar bulunmaktadır. Güran Erbek'çe projelendirilmiş, Türkiye'deki müzeler ile Anadolu ve çevresinden seçilmiş altı yüze yakın halının fotoğraflarla belgelenmiş olduğu katalog$\operatorname{lar}^{21}$ vardır. Beş cilt olarak yayınlanmış bu kitaplarda bir sayfada halının fotoğrafı diğerinde bazı motif ve desenler bir halka içine alınmış başka bir fotoğrafı ve halka içine alınmış motif ve desenlerin çizim ve adlarına yer verilmiştir. İlgi çeken başka bir araştırmanın ürünün geç dönem Batı Anadolu halılarıyla ilgili belgelerle bilgiler veren Ürer'in ${ }^{22}$ kitabıdır.

$\mathrm{Bu}$ arada bazı el sanatlarını konu alan kitaplarda halı ve düz dokumalara yer verilmiştir. ${ }^{23}$ Kilim ve Düz dokuma yaygılara genel bir bakış açısıyla eğilinmiş ve çizimlerle desteklenmiş olan kitaplardan erken tarihli olan ikisi Kenan Özbel'indir. ${ }^{24} \mathrm{Bu}$ kılavuz kitapları Belkis Acar'ın iki kitabı ${ }^{25}$ ile Ölçer'in Nils

15 Gombos Karoly, Regi Kelleti Szönyegek Altorientalische Teppiche- Old Oriental Rugs, Kereszteny Museum Esztergom 1977, Christliches Museum Zu Esztergom Hungary 1977, Christian Museum In Estergom Hungary, 1977.

16 Ferenc Batari, Five Hundred Years In The Art Of Ottoman Carpet Making, The Museum Of Applied Art, Budapest, 1986.

17 N.P. Nekrasova- K.G. Kinayeva, Moskova Sark Sanatları Devlet Müzesi Türk Azeri Ve Türkmen Seccadeleri, Çev. Cem Oğuz, Atatürk Kültür Merkezi, Ankara, 1997.

18 Şerare Yetkin, Türk Halı Sanatı, Türkiye İş Bankası, Ankara, 1991

19 Nalan Türkmen, Orta Asya Türkmen Halıları İle Tarihi Anadolu- Türk Halılarının Ortak Özellikleri, Başbakanlık Atatürk Kültür Dil ve Tarih Yüksek Kurumu Atatürk Kültür Merkezi, Ankara, 2001.

20 Bekir Deniz, Türk Dünyasında Halı ve Düz Dokuma Yaygılar, Atatürk Kültür Merkezi, 2000;

21 El Dokuması Halılar ( Turkish Handwoven Carpets), Kültür ve Turizm Bakanlığı, Katalog 1; Katalog 2; katalog 3; Katalog 4, Katalog 5 Güran Erbek Anısına, (In the Memory of Güran Erbek).

22 Harun Ürer, Haneden Ticarethaneye Batı Anadolu Halıcılı̆̆ (1836-1935) Ege Üniversitesi, Yayınları, Edebiyat Fakültesi Yayın No:139 İzmir, 2007. Van Kilims, Van Valiliği, Ankara, 1998.

23 Fatma Pamir Akbil, Türk El Sanatlarından Örnekler, Akademi Yayınları, İstanbul, 1970; Çetin Aytaç, El Dokumacılı̆̆ı, Devlet Kitapları, Milli Eğitim Basımevi, İstanbul, 1982; H.Örcün Barışta, Turkish Handicrafts, Expo 85 Yayınları, Türk Tarih Kurumu Matbaası, Ankara, 1985; H.Örcün Barışta, Turkish Handicrafts, Ministry of Culture And Tourism Publications: 974, Art Book Series: 11 ,(Expo 85 için hazırlanan genişletilmiş baskısı); H.Örcün Barışta, Türk El Sanatları, Kültür ve Turizm Bakanlığı Yayınları, 975, Sanat Eserler Dizisi, 11, Ankara, 1988,(Yukarıdaki Kitabın Türkçesi); H.Örcün Barışta,Türk El Sanatları, Genişletilmiş İkinci Baskı, Kültür BakanlığıYayınları: 2168, Sanat Eserleri Dizisi:192, Ankara, 1998; H.Örcün Barışta, Türkiue Cumhuriyeti Dönemi Halk Plastik Sanatları,Kültür ve Turizm Bakanlığı, Ankara, 2005;Taciser Onuk- Feriha Akpınarl1-H.Serpil Ortaç- Özlem Alp, Tarsus El sanatları, Kültür Bakanlığı, Ankara, 1998.

24 Kenan Özbel, Kılavuz Kitaplar, Cicim ve Sili, El Sanatları VII, C.H.P Halkevleri Bürosu; Kenan Özbel, Kılavuz Kitaplar, Anadolu Kilimleri, El Sanatları IX, C.H.P Halkevleri Bürosu.

25 Belkis Acar, Kilim ve Düz Dokuma Yaygllar, Akbank Yayınları, Süsleme Sanatları Serisi:3, 1975.Acar-Balpınar, Belkıs Kilım Cicim Zili, Sumak Turkish Fletweaves, Eren Yayınları, İstanbul, 1983;
Rüters'in yapmış olduğu malzeme- teknik analizlerini de içeren ${ }^{26}$ bir kitabı izlemektedir. Anadolu ve Yörük kilimleri konusunda genel bilgiler veren iki kitapYusuf Durul'undur. ${ }^{27}$ Aşiretleri konu alan başka bir kitap Onuk ve Akpınarlı'nındır. ${ }^{28}$ Avşar ve Türkmen kilimlerinin motif çizimleri ve adları ile dikkat çeken bir başka kitap Durul'undur. ${ }^{29}$ Bu kitap dışında motif çizimleri ile desteklenmiş iki katalog Güran Erbek'çe projelendirilmiştir. Bu kataloglarda müze ve müzeler dışında bulunan Anadolu kilimlerinden seçme iki yüz örnek bazı motiflerinin çizim ve adları ile birlikte sunulmuştur. ${ }^{30}$

Belli yörelere ait halıları konu alan kitaplar: Hereke $^{31}$, İsparta ${ }^{32}$, Yağcl bedir ${ }^{33}$, Uşak ${ }^{34}$, Bergama; ${ }^{35}$ düz dokuma yaygıları konu alan kitap Çanakkale- Ayva$\mathrm{Clk}^{36}$ kilimlerini konu alan kitaplar Eşme ${ }^{37}$ Hakkari $^{38}$ olarak sıralanabilir. Bu örnekler Valilikler ${ }^{39}$, Belediyeler ${ }^{40}$ bazı Vakıflarca ${ }^{41}$ yayınlanmış kitaplarla çoğaltılabilir.

Öte yandan bu yayınlar halı ve düz dokumaların boyar maddeleri üzerinde yapılan çalışmaları içeren yayınlar bulunmaktadır. Bunlara çeşitli üniversitelerde yapılmış araştırmaların sonucunda elde edilen bulguların paylaşıldığı doğal boyalara yönelik olan

26 Nazan Ölçer, Türk İlam Eserleri Müzesi Kilimler, Eren Yayıncılık, İstanbul, 1988.

27 Yusuf Durul, Yörük Kilimleri, Akbank, Süsleme Sanatları : 6, İstanbul, 1977; Yusuf Durul, Anadolu Kilimlerinden Örnekler, Akbank, 1985

28 Taciser Onuk- Feriha Akpınarlı, Şanlıurfa Karakeçili Kilimleri, Başbakanlık Atatürk Kültür Dil ve Tarih Yüksek Kurumu, Atatürk Kültür Merkezi, 2003

29 Yusuf Durul, Anadolu Kilimlerinden Örnekler, Akbank, 1987

30 Anatolian Kilims, 1,2, T.C. Kültür ve Turizm Bakanlığı, DÖsì 1995.

31 Önder Küçükerman, Hereke Fabrikası, Sümerbank, İstanbul, 1987

32 Önder Küçükerman, Batı Anadolu'daki Türk Halıcllk Geleneği İçinde İmir Limanı ve Isparta Halı Fabrikası, Sümer Halı, Ankara, 1990.

33 Yeşim Öztürk, Balıkesir Sındıgı Yöresi Yağcıbedir Halıları, Kültür Bakanlığı, Ankara, 1992

34 Besim Atalay, Türk Halıcılı̆̆ı Ve Uşak Halıları, Türkiye İş BankaS1, 1967.

35 Fahrettin Kayıpmaz- Naciye Kayıpmaz- Mustafa Genç, Tarihten Günümüze Bergam Halıları, Bergama Belleten 10, 2001,Bergama Kültür Ve Sanat Vakfı.

36 Bekir Deniz, Ayvacık Çanakkale Yöresi Düz Dokuma Yaygıları, Başbakanlık Atatürk Kültür Dil ve Tarih Yüksek Kurumu, Atatürk Kültür Merkezi, Ankara, 1998.

37 Neriman Görgünay, Eşme Kilimleri, Başbakanlık Atatürk Kültür Dil ve Tarih Yüksek Kurumu, Atatürk Kültür Merkezi, Ankara, 1994.

38 Recai Karahan, Dünden Bugüne Hakkari Kilimleri, Kültür ve Turizm Bakanlı̆̆ı, Ankara, 2007.

39 Hakkari Kilimleri, Hakkari Valiliği, Ankara, 1997 Van Kilims, Van Valiliği, Ankara, 1998. Kilimlerimiz, Balıkesir Valiliği, Balıkesir, 2000 Ahmet Aytaç, Hotamiş Türkmen Kilimleri, Konya Valiliği, Kültür ve Turizm Müdürlüğü, Konya, 2003.

40 Ahmet, Aytaç, Yukarıçiğil Kilimleri, Yukarıçiğril Belediyesi, Konya 2009 .

41 Uluslararası Eşme Kilim Festivali Türkiye Kilimciliğinin Üretimve Pazarlama Sorunları Sempozyumu, Turizm Geliştirme Vakfı, Ankara, 1995. 
bilgileri ${ }^{42}$ ve alan çalışmalarını da kapsayan kitaplar ${ }^{43}$ ile Marmara Üniversitesince 20. yüzyılda başlatılan 21. Yüzyılda da devam edilen laboratuar çalışmalarının kazanımları olan makale ${ }^{44}$ ve kitaplar. ${ }^{45}$ örnek verilebilir. Marmara Üniversitesinde sürdürülen çalışmalarla pek çok tekstil örneğinin boyar maddeleri analizleri yapılmış ve bulgular Turkish Cultural Foundation tarafından internet ortamına aktarılmıştır. ${ }^{46}$

$\mathrm{Bu}$ konuda yayınlanmış makaleler ve bildiriler sayıca çoktur ve kirkitli dokumaların araştırmalarının geniş bir evrene ulaştı̆̆ına işaret etmektedir. Bunlardan erken tarihli yurt dışı bir makaleyle konuya ilgi çeken Rüçhan Arık'tır. ${ }^{47}$ Başka iki makale ise Şerare Yetkin'indir. ${ }^{48}$ Bu konuda bu dala büyük katkıları olan Arış Dergilerinde yayımlanmış makaleler bulunmaktadır. ${ }^{49}$ Bunlar arasında Türk halı sanatının genel gelişmesi ve yeni keşifleri konu alan makaleler $^{50}$ yanı sıra müze ve koleksiyonlardaki örnekleri tanıtmağa ${ }^{51}$, bazı yörelerdeki örnekleri belirleme

42 Öner Eyüpoğlu-Itır Okaygün- Füsun Yaraş, Doğal Boyalarla Yün Boyama Uygulamalı ve Geleneksel Yöntemler, Uygulama, A.Ş., İstanbul, 1983.

43 ; İsmail, Öztürk, Doğal Bitkisel Boyalarla Yün Boyama, Ürün Yayınlar1: 15, Temel Kaynak Dizisi 04.

44 Recep Karadağ, "Doğal Boyar Maddeler",Arış, Başbakanlık Atatürk Kültür Dil ve Tarih Yüksek Kurumu Atatürk Kültür Merkezi, 1997, S.2, s.38-51.

45 Recep Karadağ, Doğal Boyamacılı, Kültür ve Turizm Bakanlığı, 2007.

46 Bk. http://www.turkishculturalfoundation . org/lab/tr/portfolyo/ boyarmadde-analizi.

47 Rüçhan Arık,"Turkish Landscape Carpets", Halı, I, No 2, London 1978, s. 122-127.

48 Şerare Yetkin, “Yeni Bulunan Hayvan Figürlü Halıların Türk Halı Sanatında Yeri", Sanat Tarihi Yıllı̆̆ı, İstanbul Üniversitesi Edebiyat Fakültesi, Sanat Tarihi Enistitüsü, 1972-1973, V.5, s. 145, 146; Şerare Yetkin, "Türk Halı Sanatı", Başlangııından Bugüne Türk Halı Sanatı, Türkiye İş Bankası, 1993, s.311-342.

49 İsmail Öztürk-Gonca Karavar, Türk Halı Kilim Biblioğrafyası,, Arış, Başbakanlık Atatürk Kültür Dil ve Tarih Yüksek Kurumu Atatürk Kültür Merkezi ,1997, S.I,S.154-157

İsmail Öztürk-Gonca Karavar, Türk Halı Kilim Biblioğrafyası II,Arış, Başbakanlık Atatürk Kültür Dil ve Tarih Yüksek Kurumu Atatürk Kültür Merkezi ,1997,S.2,s.76-89.

İsmail Öztürk-Gonca Karavar, Türk Halı Kilim Biblioğrafyası III, Arış, Başbakanlık Atatürk Kültür Dil ve Tarih Yüksek Kurumu Atatürk Kültür Merkezi ,1997,S.3 s.116-121

İsmail Öztürk-Gonca Karavar," Türk Halı Kilim Biblioğrafyası", IV, Arış, Başbakanlık Atatürk Kültür Dil ve Tarih Yüksek Kurumu, Atatürk Kültür Merkezi ,1998,S.4,s. 120-122

50 Oktay Aslanapa, "Türk Halı Sanatının Tarihi Gelişmesi”, Arış, Başbakanlık Atatürk Kültür Dil ve Tarih Yüksek Kurumu, Atatürk Kültür Merkezi , 1997, S.3, s. 18-25; Oktay Aslanapa," Türk Halı Sanatında Yeni Keşifler", Arış, Başbakanlık Atatürk Kültür Dil ve Tarih Yüksek Kurumu, Atatürk Kültür Merkezi ,1997,S.2,s. 10-17.

51 Bekir Deniz, "Aksaray Müzesi Halıları", III. Ulusal El Sanatları Sempozyum Bildirileri,23- 25 Kasım 1983-İzmir, 1984, s.112-119. Sema Koç, "Ankara Etnografya Müzesi Halı Kilim Koleksiyonu", Arış, Başbakanlık Atatürk Kültür Dil ve Tarih Yüksek Kurumu, Atatürk Kültür Merkezi ,1998, s. 104-113. Suzan Bayraktar," Vakıflar Genel Müdürlüğü Halı ve Kilim Koleksiyonu", Arış, Başbakanlık Atatürk Kültür Dil ve Tarih Yüksek Kurumu Atatürk Kültür Merkezi, 1997, S.2,s.88-103;

Naci Bakırcı," Mevlana Müzesi Halı Kumaş Seksiyonunda Sergilenen Türk Halıları", Arış, Başbakanlık Atatürk Kültür Dil ve Tarih Yüksek Kurumu, Atatürk Kültür Merkezi,1997, S.1, s.120-133. H.Örcün Barışta, “Bir Müzayede Sergisinden Sağlanan Bilimsel ve belgelemeğe yönelik çalışmalar vardır. Bunlardan halıları tanıtmağa yönelik olanlar Taşpınar ${ }^{52}$, Kula $^{53}$, Gördes $^{54}$, Ladik ${ }^{55}$, Kırşehir $^{56}$, Mucur ${ }^{57}$, Milas ${ }^{58}$, Kozak Bergama $^{59}$, Aksaray $^{60}$, Arısama $^{61}$, Yunddağ ${ }^{62}$, Uşak ${ }^{63}$, Konya $^{64}$, İsparta ${ }^{65}$, Nevşehir ${ }^{66}$, Konya SarayönüLadik $^{67}$, Konya Yükselen ${ }^{68}$, Taşkale' $\mathrm{de}^{69}$ bulunan halılar şeklinde sıralanabilir. Bunlara Divriği Ulu Camide Bulunan Osmanlı Saray Üslubundaki Kilimler ${ }^{70}$, Bardız kilimleri ${ }^{71}$, Yozgat kilimleri ${ }^{72}$, Afyonkarahisar ki-

Katkıya Bir Örnek Uçaklı Halı", Kuruluşunun 150. Yılında Türk Müzeciliği Sempozyumu, Genelkurmay Askeri Tarih ve Stratejik Etüd Dairesi Başkanlığı Yayınları, Genel Kurmay Basımevi, Ankara, 1997, s. 138-142.

H.Örcün Barışta, “Cumhuriyet Döneminin Ankara'ya Armağanlarından Ankara Beypazarı Kültür ve Sanat Müzesi Halıları Üzerine", Cumhuriyetin 80. Yilında Her Yönüyle Ankara, Gazi Üniversitesi- Ankara Büyükşehir Belediyesi, 2004, s.201-206- Fotoğraflar 351-357

H.Örcün Barışta, "Konya Müzelerinde Bulunan Geç Dönem Halıları Üzerine",s.3-12.II.Uluslararası Türk El Dokumaları (Tekstil) Kongresi ve Sanat Etkinlikleri, Selçuk Üniversitesi,Selçuklu Araştırma Merkezi Başkanlığı, Konya, 2009.

52 Bekir Deniz, “Taşpınar Halıları”, Sanat Dünyamız, Yapı ve Kredi Bankas1, 1982, S.25,s. 18-22

53 Bekir Deniz, "Kula Halıları", Bilim,Birlik, Basarı, 1985, S.43, s.13-19.

54 Bekir Deniz, "Gördes Halıları" Bilim, Birlik, Başarı, 1986,S. 45,s. 13-19.

55 Bekir Deniz, "Ladik Halıları", Bilim, Birlik, Başarı, 1986,S.46,s. 13-18.

56 Bekir Deniz, "Kırşehir Halıları" Bilim, Birlik, Başarı, 1986, S.47, S. 18-24.

57 Bekir Deniz,"Mucur Halıları", Bilim, Birlik, Başarı, 1987,S.48,s. 20-24

58 Bekir Deniz, “ Milas Halıları”, Bilim, Birlik, Başarı, 1987, S. 49,s. 13-20

59 Bekir Deniz, "Kozak Bergama Yöresi Halıları”, Arış, Başbakanlık Atatürk Kültür Dil ve Tarih Yüksek Kurumu, Atatürk Kültür Merkezi, 1997, N.2, s.18-37.

60 Bekir Deniz, “ Geçmişten Günümüze Aksaray Halıları”, Arış, Başbakanlık Atatürk Kültür Dil ve Tarih Yüksek Kurumu, Atatürk Kültür Merkezi, 1998, s.90-103.

61 Bekir Deniz,"Arısama Halıları", Lale, 1987, S.5,s.9-15.

62 Bekir Deniz, "Yöre Özellikleriyle Yunddağ Halıları", Dokuzuncu Milletlerarası Türk Sanatları Kongresi, An kara, 1995,s.33-46.

63 A.Fulya Bodur,"Batı Anadolu Uşak Halıları" Türk Edebiyatı, 1984, S. 132, s. 33-34

64 A.Fulya Bodur, "Halıcılık Tarihine Kısa Bir Bakış ve Konya Halıları", Vakıflar Dergisi, Vakıflar Genel Müdürlüğü,1988,S. XX,S. 105-114.

65 H.Örcün Barışta, "Isparta Halıcılığı Üzerine”, Kamu ve Özel Kuruluşlarla Orta Öğretim ve Üniversitelerde El Sanatlarına Yaklaşım ve Sorunları Sempozyumu Bildirileri, Kültür Bakanlığı, Halk Kültürlerini Araştırma Geliştirme Genel Müdürlüğü,- Dokuz Eylül Üniversitesi Rektörlüğü, Ankara, 1994, s.53-66.

66 H. Örcün Barışta, "19. Yüzyıla Ait Türk Halılarından Nevşehir'de Bulunan Beş Örnek", IX. Milletlerarası Türk Sanatları Kongresi, Ankara, 1995,C.I,S. 265-273

67 H.Örcün Barışta, “Sarayönü ve Ladik'te Bulunan Türk Halılarından Bazı Örnekler", Vakıflar Dergisi, 1995, N.XXV,s. 211-234.

68 H.Örcün Barışta., Konya Yükselen Eski Bilecikten Bazı Halı Örnekleri, El Sanatları Dergisi, Selçuk Üniversitesi, Türk El Sanatlarını Araştırma ve Uygulama Merkezi, 1997, N. I, s.99-112.

69 H.Örcün Barışta, , Karaman Taşkale Halılarından Örnekler“, Erdem, Halı Özel Sayısı I, Atatürk Kültür Dil ve Tarih Yüksek Kurumu, Say1:28, C.10, 1999, s.34-48, 173-184.

70 ŞerareYetkin, "Divriği Ulu Camide Bulunan Osmanlı Saray Üslubundaki Kilimler", Belleten, V. XLII, s. 165.

71 Neriman Görgünay, "Bardız Kilimleri”, II.Milletlerarası Türk Folklor Kongresi, V.5, Maddi Kültür, Başbakanlık Basımevi, Ankara, 1983, S.89-101.

72 Bekir Deniz, "Yöre Özellikleriyle Yozgat Kilimleri", Arkeoloji ve Sanat Tarihi Dergisi, Ege Üniversitesi Edebiyat Fakültesi Yayını,İzmir, 1990, s.69-84 
limleri ${ }^{73}$ Emirdağ kilimleri ${ }^{74}$, Sanfransisko'daki Anadolu Kilimleri (Anatolian Kilim's In Sanfrancisco) ${ }^{75}$, Anadolu Brokarlarının Sınıflaması ${ }^{76}$ Emirdağ ve Çevresinin Kirkitli Dokumalar $1^{77}$ Antalya ${ }^{78}$ Yundda $\breve{g}$ Yöresi Kilim ve Düz Dokuma Yaygılar1 ${ }^{79}$ Antalya Gazipaşa kirkitli dokumaları ${ }^{80}$ eklenebilir. Bu örnekler içinde halı ve düz dokumalara yer verilmiş el sanatları ile ilgili bazı makale ve bildirilerle ${ }^{81}$ çoğaltılabilir.

\section{Seçme Kaynaklardan Sağlanan Kazanımların Değerlendirilmesi Aşamasında Beliren Duru- mun Düşündürdükleri}

Yukarda sıralanan büyük kazanımlar sağlanan, görsellerle desteklenmiş, yerli ve yabancı kamu kurum-

73 Ahmet Topbaş, "Afyonkarahisar ve Yöresi Kilimleri, Kültür ve Sanat, Türkiye İş Bankası Yayınları, 1994, S. 21, s.54-55.

74 Adnan Güçlü, "Emirdağ Yöresi Kilimlerinden Örnekler,"Emirdağ Kültür Araştırmaları Sempozyumu, Tebliğler, 1-3 Haziran 1995. Emirdağ Kaynakamlığı, Eskişehir.

75 George O. Bannon," Anatolian Kilim's In Sanfrancisco", Oriental Rug Review, 1991, V. XII, N.1, s.32.

76 Marla Mallett, "The Classification of Anatolian Brocades", Oriental Rug Review, V.XII, N.1, 1991, Oct./Nov.,p.17.

77 H.Örcün Barışta, "Emirdağ ve Çevresinin Kirkitli Dokumaları", Sanatsal Mozaik, N.18, s.22-25.

78 Musa Seyirci “Antalya'daki Karakoyunlu Așireti ve Dokumaları", IV. Milletlerarası Türk Halk Kültürü Kongresi Bildirileri, Halk Kültürlerini Araştırma ve Geliştirme Genel

79 Bekir Deniz, "Yunddağ Yöresi Kilim ve Düz Dokuma Yaygıları", IV Milletlerarası Türk Halk Kültürü Kongresi ,Ankara, 1992, Maddi Kültür, C.5,s.69-84.

80 Bekir Deniz Gazi Paşa (Antalya Yöresi) Kirkitli Dokumaları, GSEI, Güzel Sanatlar Etkinlikleri Bildiriler, Antalya, 2008, s. 113-101.

81 H.Örcün Barışta, “Divan-1 Lügat-it Türk'de Dokuma ve Dokumanın Üzerine Yapılan Bezemeler

Çevresinde Kümelenen Ifadeler", 2.Ulusal El Sanatları Sempozyumu Bildirileri, Dokuz Eylül Üniversitesi Güzel Sanatlar Fakültesi Yayınları, İzmir, 1982, s. 32-39; H.Örcün Barışta, "Selçuklu Dönemi Tekstil Sanatı Üzerine", Antalya 3. Selçuklu Semineri Bildiriler, Antalya Valiliği Yayınları, İstanbul, 1989, s.18-31; H.Örcün Barışta, "Karaman Taşkale Dokumacılı̆̆ı", Türk Halk Kültürü̈ Araştırmaları, Kültür Bakanlığı, Halk Kültürlerini Geliştirme Genel Müdürlüğü Yayınları: 171, Ankara, 1992, s. 1-12; H.Örcün Barışta, "19-20. Yüzyıl İç Anadolu ve Orta Akdeniz Bölgesi Türk Kirkitli Dokumaları Üzerine", Türk Soylu Halkların Hall,Kilim, ve Cicim Sanatı Uluslararası Bilgi Şöleni Bildirileri, Atatürk Kültür Merkezi Başkanlığı Yayınları, 1998, s.39-56; H.Örcün Barışta "Türk Dünyası El Sanatları Üzerine", Türk Dünyası Özel Sayısı I, Yeni Türkiye, 1997, s.617-630; H.Örcün Barıșta, „Konya'nın Osmanlı İmparatorluğu Dönemi El Sanatları“, Uluslararası Kuruluşunun 700. Y1l Dönümünde Bütün Yönleriyle Osmanlı Devleti Kongresi, Selçuk Üniversitesi, Konya, 2000, s. 845-854; H.Örcün Barışta, "Hakkari El Sanatları Sergisinin Ardından-Dünden Bugüne Hakkariden Bazı Tekstil Ürünleri“", Dağların Kenti Hakkari, S. 17, 2000, s.3-6; H.Örcün, Barıșta, „Örcün Köyü Tekstil Sanatları Üzerine“, Dünden Bugüne Karaisall, Kuvayı Milliye Şenlikleri Konferanslar Dizisi, Adana Karaisali, 2001, s.91-102; H.Örcün Barışta, "Osmanlı İmparatorluğu Dönemi Halıları ve İşlemeleri Arasındaki Benzerlikler", Prof.Dr.Zafer Bayburtluoğlu Armağanı, Sanat Yazıları, Kayseri, 2001, s. 65-71; H.Örcün Barışta, "Bazı Gözlemler Işığında Göçer Çadırları", VIII. Ortaçağ ve Türk Dönemi Kazları ve Sanat Tarihi Araştırmaları Sempozyumu, Sakarya Üniversitesi, Fen Edebiyat Dergisi, 2005, C.7,S.1, s.36-50; H.Örcün Barışta, "Halı Sanatının Bazı Azeri, Türkmen, Kırgız ve Kazak Örnekleriyle Benzerliklerine Dair", 3.Internatioal Symposium Azerbaijan Carpet And Traditional Applied Arts, Ministry of Culture of the Repuıblic of Azarbaijan, Baku-Elm-2005, 102-107; H.Örcün, Barışta, “Türk Tekstil Sanatlarını Süsleyen Konulardan Bazı Motifler", Türk Dünyası Araștırmaları, Prof.Dr. Oktay Aslanapa Özel Sayısı,Türk Dünyası Araştırmaları Vakfı,2009, S.183, s.25-46. ları, diğer kurumlar ve özel kişilerce yapılmış, araştırmalara dayanan bu yayınlar Anadolu ve çevresinde yapılmış örneklerle çok güçlü bir Türk kirkitli dokuma sanatının varlığını gözler önüne sermektedir. Farklı disiplinlerin bakış açılarından farklı yöntemler izleyerek yapılmış sayıca çok bu çalışmaların çok geniş disiplinler arası bir alana yayılmış olduğu görülmektedir. Bunların:

Bir grubu kültür varlığı nitelindeki kirkitli dokuma örneklerinin görsel plastik niteliklerini ayrıştırarak başka deyişle analizlerini yaparak benzer bir sistematikle belgelemeğe;

Bir grubu bazı örnekleri belirlemeğe; bir grubu bazı örnekleri envanter fişleri ile kayıt etmeğe,

Bir grubu kirkitli dokuma örneklerinden oluşan bu engin hazineyi farklı başlıklar altında genel bilgiler sunarak tanıtmağa yönelik olarak hazırlanmıştır.

Hepsinde görseller kullanılmıştır. Bunların:

Bazılarında aynı zamanda birer belge olan görsellerin kullanılışında da farklılıklar gözlenmektedir.

Bazı yayınlarda metni süslemek için yerleştirilmiş bir kirkitli dokuma fotoğrafı, bazı yayınlarda metni tamamlamak için çekilmiş fotoğraflar ve yapılmış bir çizimler yer almaktadır.

Genellikle farklı grafiksel yollarla çizilmiş motif ve kompozisyonları içeren çalışmalar arasında bazı farklı bakış açılarıyla çekilmiş, bazıları yeterli açıklamasız fotoğraflarla tamamlanmış bilgiler vardır.

Bakış açısı doğrultusunda çeşitli konularda hepsi yarar sağlayan bu araştırmaya dayalı yayınlar içerdikleri kirkitli dokuma örneklerinin kayıt sisteminde yayın türü ve işlevine bağlı olarak bazı farklılıklara göstermektedir. Bu yayınlar başlıca kültür varlığının plastik özelliklerinin ayrıştırılmasına başka deyişle analizine yönelik gözlem fişleri kullanarak oluşturulmuş katologlara dayanarak gelişen çalışmalar; kültür varlığını müze ve koleksiyonlarda kullanılan envanter fişleri kullanılarak, belli özellikleri ile belgelenmesini amaçlayan çalışmalar; kültür varlığı niteliğindeki kirkitli dokumaları belirlerken, tanıtırken sunulan genel bilgiler arasına serbest bir kurgu içinde yarleştirilmiş ilgili fotoğraf ve çizimlere bütünleşmiş çalışmalar vb. gibi başlıklar altında kümelenmektedir. Her biri kendi içinde bütünlük gösteren farklı amaçlarla kaleme alınmış ve farklı grafik düzeniyle kurgulanmış, hepsi araştırmaya dayanan bu yayınlar:

Toplu bir bakışla içerdikleri kirkitli dokuma örnekleri üzerinde genel bir değerlendirmeyi kısa yoldan gerçekleştirmeyi olanaksız kılmakta,

Önce bir sınıflama sonra bir döküm yaparak bu yayınlardaki bilgi ve görselleri yeniden inceleyerek analiz etmeyi gerektirmekte, 
Sağlıklı bir sonuca ulaşmayı güçleştirmektedir.

Bu güçlük kirkitli dokuma örneklerin nesnel değerlerinin bir örnek yöntemle ele alınmamış olduğu gözlenen bazı çalışmalarda seçilen kirkitli dokuma örneklerindeki motiflerin, kompozisyonların gözlenen nesnel değerleri dışında bunların üzerinde yapılan öznel yorumlarla ileri sürülen adlandırmalar, bunların anlam yükü konusunda farklı yaklaşımlar getiren bazı yayınlarla daha da farklı boyutlara taşınmaktadır.

Bazı farklı bakış açılarından kaynaklanan farklı yöntemle sunulmuş çalışmalardaki kirkitli dokuma örnekleri bir birlerinden kopmakta ve bu alanla ilgili araştırmalar arasındaki bilgi alışverişini zorlayan bir durum yaratmaktadır. Bu durum bu alanda beliren problemleri çözücü bir yaklaşımla yeniden eğilmenin, yeni bir bakış açısından değerlendirme yapmanın ve bir sonuca doğru yönlenebilme sürecinde problemleri çözebilme yollarını aramanın zamanı gelmiş olduğuna işaret etmektedir. Ancak problemlerin çözümünde önce kullanılacak yöntemde nasıl bir yol izleneceği konusunda bir birliğe varılması ve izlenecek yöntemle bazı sorunları çözmek yoluna gidilmesinin yararlı olabileceğini düşündürmektedir.

Öte yandan yukarda sıralanan yayınların nitelik ve niceliği Türk sanatının kirkitli dokumalar alanının son derece zengin olduğunu, bu alandaki örneklerin belli bir sistematikle belgelenerek bir bilgi bankasında derlenmesi için ülkemizde bir bilgi bankası kurulması ve bir Türkiye kirkitli dokuma atlası oluşturma zamanın gelmiş olduğunu ortaya koymaktadır. Böyle bir yapılamanın gereğini bu alandaki Türk kültür varlıklarının Anadolu ve çevresi dışındaki yabancı ülkelerin müze ve koleksiyonlarına yayılmış örnekleri ile Türkiye Cumhuriyeti sınırları dışında yaşayan Türk soylu halkların örnekleri daha da güçlendirmektedir. Bu bağlamda kurulaması ön görülen bilgi bankasından sağlanacak bilgilerle yapılacak uluslar arası ve disiplinler arası (interdisipline) çalışmalarla daha geniş bir coğrafyaya yayılan bir Türk dünyası kirkitli dokuma atlası hazırlanmasına olanak sağlanacaktır.

Oluşturulması önerilen kirkitli dokuma atlaslarının gerçekleşebilmesi için bazı ön çalışmalar ve hazırlıklar yapılmalıdır. Bu çalışmalarda:

Vazgeçilmez bir kaynak oluşturacak olan, veri tabanının belli ilkeler doğrultusunda programlanması,

Bilgi ve görseller içerecek havuzunun yer alacağı bilgi bankasının kayıt sisteminin iletişimi sağlaması,

Bilimsel sistematiğe uygun bir bütünlük içinde aynı kalıpla kayıt yapılmasına olanak veren bir biçimde düzenlenmesi,

Problemlere neden olacak kayıt biçimlerinden kaçınılmalısı sağlanmalıdır.
Aşama aşama hazırlanacak bir hareket planı ile önce bir veri tabanı oluşturmaya başlanmalıdır. Bu veri tabanını hazırlıkları yapılırken günümüze değin farklı yöntemlerle yapılmış araştırmaların ürünü olan bazı yayınlardaki kirkitli dokuma örneklerin plastik özelliklerinin kayıt sisteminin farklı oluşundan kaynaklanan bazı sorunlar ardı edilmemelidir. Kisaca:

Farklı yöntemlerle kayıt edilmiş araştırmaların başlıca sorunları:

Verilerin araştırmacılar tarafından yeniden sorgulanması,

Verilerin irdelenmesi aşamasında araştırmacıları çok zaman kaybı ile çözümlenemeyecek bazı problemlerle karşı karşıya bırakması,

Verilerden yola çıkılarak döküm tabloları oluşturulamaması,

Döküm tabloları olmadan sağlıklı bulgulara varılamaması,

Döküm tabloları olmadan çizelgelere geçilemeyişi,

Sağlıklı bir ölçme ve değerlendirme ile karşılaştırmalar yaparak sonuca ulaşmayı geciktirmesi,

şeklinde sıralanabilicek bu sorunlara çözüm yolları aranmalıdır. Bu sorunlara eklenen terminoloji ve yorum farklılıkları problemleri sorunların boyutları iyice geliştirmesine dayanarak daha ayrıntılı bakış açısıyla konuya eğilinmelidir.

Bu bağlamda önce her kirkitli dokuma örneğinin varlığını belirlemek sonra beliren bu kültür varlığının üzerinde benzer bir kalıpla ayrıntılı bir nesnel plastik özelliler analizi yapma olanağı veren, odak noktaları madde madde belirtilmiş fişlerle kayıt yaparak sağlam bir veri tabanı hazırlama, belirlenen verilerden bulgulara ulaşma ve sonra senteze gitme olanağı sağlayacak kayıt fişleri hazırlanmalıdır. Bu yolla gözle görülen gerçeklerin sağlıklı, açık seçik yalın ifadeli maddeler biçiminde sıralanmasıyla bir plastik kimlik kazanan örneklerin öznel değerlerine ve yorumuna ulaşacak düzeye erişecek bir zemin oluşturulmalıdır.

$\mathrm{Bu}$ bağlamda çeşitli araştırmalarda kullanılmış yöntemler bulunmaktadır. ${ }^{82}$ Bazı araştırmalarda halı ve kilim inceleme gözlem fişleri oluşturulmuştur. Bunlardan en son yayınlanan bir örneği ${ }^{83}$ bulun-

82 Harun Ürer, Emirdağ(Afyon) Yöresi Düz Dokuma Yaygılar, E.Ü.Sosyal Bilimler Enistitüsü,Türk ve İslam Sanatı Anabilim Dalı, İzmir, 1997, (Yayınlanmamış Yüksek Lisans Tezi); Harun Ürer, Yabancı Şirketlerin Batı Anadolu Bölgesi ndeki Halıcllk Faaliyetler Ve Bunun Geleneksel Türk Halı Sanatına Etkileri, Ege Üniversitesi, Sosyal Bilimler Enistitüsü, Sanat Tarihi Ana Bilim Dalı, İzmir, 2002. (Yayımlanmamış Doktora tezi);

83 Barışta, agm., "Türk Tekstil Sanatlarını Süsleyen Konulardan Bazı Motifler", s.45. 
maktadır. Farklı bir yaklaşımla üzerinde araştırmalar yapılmış farklı bir belgeleme sistemi ile konuya eğilinmiş lisans, yüksek lisans ve doktora tezleri vardır. Bu tezlerin bir grubunda bir tür kimlik belgesi olan bir örnek gözlem fişleri kullanılarak kültür varlıklarının nesnel plastik değerlerini ölçme ve değerlendirme yapma olanağı sağlanmış; envanter fişinden farklı açık, kısa bilgilerle çok işlevli sorgulamaya yönelik bir yaklaşımla belli yörelerde ya da müzelerde bulunan halı ve kilimler belgelenmiştir. Barışta'nın danışmanlığında yapılmış bir grup tez kültür varlığının nesnel değerlerini belirlemek için oluşturulmuş ortak bir gözlem fişi örneği, gözlem fişlerinden oluşturulacak kataloğ ve kataloğdaki verilerin belirtke döküm tablolarında toplanması, belli ölçme ve değerlendirme kriterleri ile oluşturulmuş belirtke döküm tablolarında yapılacak çalışmalarla sayısal değerlerin belirlenmesi (puantaj) çizelgelere geçirilişi böylece gözlenen nesnel bulgulara varış konusunda bir birliğe yardımcı olabilir. Örneklersek: Gülhan Kuşhan'ın Bardız Kilimleri84; Fatih Toğay'ın 16-17-18. Yüzyıllara Ait Uşak Halılarının İstanbul Türk ve İslam Eserleri Müzesi, İstanbul Vakıflar Halı Müzesi Ve Edirne Müzesi'ndeki Örnekleri ${ }^{85}$; Saim Cirtil'in Kayseri Müzesi'ndeki Halı Ve Kilimler ${ }^{86}$; Hakan Tazecan'ın, Saf Kilim Ve Seccadeler Üzerine Bir Deneme $^{87}$; Recai Karahan'ın, Konya Müzelerinde Bulanan Kilimler ${ }^{88}$; Hafize Pektaş'ın, Karapınar Ev Ve Camilerinde Bulunan Kilimler; ${ }^{89}$ Serap Uçan'ın, Vakıflar Genel Müdürlüğü Halı Ve Kilim Sergisinde Sergilenen Anadolu Kaynaklı Halılar ${ }^{90}$ konulu tezlerinin gözlem fişleri.

Kısaca bir sempozyum bildirisinin sınırlı zaman birimi kapsamında sunmağa çaba harcadığımız kirkitli dokuma alanında kaleme alınmış, kitap, makale, bildi-

84 Gülhan Kuşhan, Bardız Kilimleri, Gazi Üniversitesi, Sosyal Bilimler Enistitüsü, Ankara, 1986, (Yayımlanmamış Yüksek Lisans Tezi)

85 Fatih Togay, 16-17-18. Yüzullara Ait Ușak Hallarının istanbul Türk ve İslam Eserleri Müzesi, İtanbul Vakiflar Halı Müzesi Ve Edirne Müzesi'ndeki Örnekleri, Gazi Üniversitesi, Sosyal Bilimler Enistitüsü, Ankara, 1987, (Yayımlanmamış Yüksek Lisans Tezi)

86 Saim Çirtil, Kayseri Müzesi'ndeki Halı Ve Kilimler, Selçuk Üniversitesi Sosyal Bilimler Enistitisü, Arkeoloji Sanat Tarihi Anabilim Dalı, Sanat Tarihi Bilim Dalı Konya, 1991, (Yayımlanmamiş Yüksek Lisans Tezi)

87 Hakan Tazecan, Saf Kilim Ve Seccadeler Üzerine Bir Deneme, Selçuk Üniversitesi Sosyal Bilimler Enistitisü, Sanat Tarihi Anabilim Dalı , Konya, 1991. (Yayımlanmamış Yüksek Lisans Tezi)

88 Recai Karahan, Konya Müzelerinde Bulanan Kilimler, Selçuk Üniversitesi Sosyal Bilimler Enistitisü, Arkeoloji Sanat Tarihi Anabilim Dalı, Sanat Tarihi Bilim Dalı Konya, 1992. (Yayımlanmamış Doktora Tezi)

89 Hafize Pektaş, Karapınar Ev Ve Camilerinde Bulunan Kilimler, Selçuk Üniversitesi, Sosyal Bilimler Enistitüsü, El Sanatları Anabilim Dalı, Konya, 1992. (Yayımlanmamış Yüksek Lisans Tezi)

${ }^{90}$ Serap Uçan, Vakıflar Genel Müdürlüğü Halı Ve Kilim Sergisinde Sergilenen Anadolu Kaynaklı Halılar, Gazi Üniversitesi,Fen Edebiyat Fakültesi Sanat Tarihi Bölümü Sanat Tarihi Anabilim Dalı, Ankara,2000. (Yayımlanmamış Lisans Tezi) ri vb. gibi araştırmaya dayalı, seçme yazılı kaynaktan yola çıkılarak yapılan durum belirlenmesi bu alanda zengin örneklerin varlığını ve bunların belli bir sistematikle kayıt edilmesi gereğini ortaya koymaktadır. Beliren bu durum kayıt aşamasında bir bilgi bankası kurulmasını ve buradan sağlanacak bilgi ve görsellerle bir Türkiye kirkitli dokuma atlası hazırlanmasının zamanı gelmiş olduğunu düşündürmektedir. Giderek daha geniş bir coğrafyaya yayılan bir Türk dünyası kirkitli dokuma atlası hazırlanmasına olanak sağlayacak böyle bir bilgi bankası kurulması hazırlıkları aşamasında çok yol alınmış olduğu gözlenen, farklı bakış açılarıyla farklı disiplinlerce kaleme alınmış, hepsi yarar sağlayan, araştırmaya dayalı yazılı kaynaklar kuşkusuz yarar sağlayacaktır. Ancak bu yazılı kaynakların üzerinde yapılan toplu değerlendirme bazı problemlerin varlığına işaret etmektedir. Bu problemlerden bir tanesi kayıt sisteminde kullanılması gerekli olan gözlem fişlerinde belirmektedir. Sanat tarihi ve halkbilim bağlamında bu problemleri ortadan kaldırmak için araştırmanın bulgulara dönüştürülecek verileri derleme aşamasında üzerinde çalışılan kirkitli dokuma örneğinin plastik özelliklerinin ve bu bağlamda özgün, anonim, geleneksel, üniversal, endüstriyel vb gibi niteliklerinin belirlenmesinde vaz geçilmez başvuru kaynağı olan, gözlem fişlerinin oluşumuna önem verilmeli ve bir örnek gözlem fişi kullanılması sağlanmalıdır. Sonuç olarak denilebilir ki bir tür çok işlevli kimlik belgesi olan gözlem fişleri aracıllğıyla her örneğin plastik özellikleri ile sağlıklı, çok işlevli bir kimlik kazanması ve plastik sanatlar ailesi içinde önce yerini alması, varlığının belirlenmesi sonra üzerinde çalışılması ve yorumlar yapılması sağlanmalıdır. Aşağıda üzerinde tartışabilecek ve eklemeler yapılabilecek bir gözlem fişi örneği sunulmuştur.

Not:

Gözlem fişi örneği üzerinde konu ile ilgili anabilim ve anasanat dallarından oluşturulacak bir çekirdek komisyonun görüşleri alınmalıdır.

Benzer bir olgu kirkitli dokumalarla ilgili fotoğraf, çizim v.b gibi görsellerin tasarımlarının nasıl olacağı; kirkitli dokumalarda kullanılan gereçlerin ve bunların yapılış tekniklerinin çizgisel yolla nasıl aktarılacağı için söz konusudur. 


\section{HALI INNCELEME GÖZLEM Fişi ÖRNEĞi}

Örnek No:

Levha No:

Fotoğraf No:

Çizim No:

İnceleme Tarihi:

İlgili Müze/ Koleksiyon:

Koleksiyonun Açık Adresi:

Fotoğraflar

(Halının yüzü ve ters yüzü)

Envanter No:

Koleksiyona Geliş Tarihi:

Koleksiyonda Yeri:

Onarım Görüp Görmediği:

Bugünkü Durumu:

Boyutlar1:

Zemin Boyutları:

Kenar Suyu Boyutları:

1 -

$2-$

3- gerekirse ekleyiniz

Türü:

Kullanılan Malzeme:

Çözgü:

Atkı:

Düğüm:

Saçak:

Uygulanan Düğüm Türü:

Seçilen Renkler:

1 -

$2-$

3- gerekirse ekleyiniz

Seçilen Konu:

Zemin Motifleri:

1 -

$2-$

$3-$

$4-$

gerekirse ekleyiniz.

Kenar Suyu Motifleri:

$1-$

Düğümün Yöredeki Adı:

Kaynak Kişi:

Renklerin Yöredeki Adı:

Anlam Yükü

Kaynak Kişi:

Türün Yöredeki Adı:

Kaynak Kişi:

Malzemenin Yöredeki Adı:

Kaynak Kişi:

Anlam Yükü:

Kaynak Kişi:

Motiflerin Yöredeki Adı:

Motiflerin Yöredeki Adı:
Anlam Yükü: Kaynak Kişi:

$2-$

$3-$

$4-$

gerekirse ekleyiniz

Birimlerin Biçimlendirmesi:

Kompozisyon: Yöredeki Adı:

Anlam Yükü:

Taslak Çizim:

Kaynak Kişi:

Kaynak Kişi Künyeleri:

Halı İle İlgili Yayınlar:

Motiflerin Milimetrik Kağıt Üzerine Çizimi:

Zemin:

1 -

$2-$

$3-$

$4-$

gerekirse ekleyiniz

İşlenilen konu maddesindeki sıra izlenerek çizimler yapılacaktır.

Kenar Suyu:

$1-$

$2-$

$3-$

$4-$

gerekirse ekleyiniz.

İşlenilen konu maddesindeki sıra izlenerek çizimler yapılacaktır. 
Kaynaklar

Acar, Belkıs (1975), Kilim ve Düz Dokuma Yaygılar, Akbank Yayınları, Süsleme Sanatları Serisi:3.

Acar- Balpınar, Belkıs (1983), Kilım Cicim Zili, Sumak Turkish Fletweaves, İstanbul: Eren Yayınları.

Akbil, Fatma Pamir (1970), Türk El Sanatlarından Örnekler, İstanbul: Akademi Yayınları.

Anatolian Kilims (1995), 1,2, T.C. Kültür ve Turizm Bakanlı̆̆ı, DÖSIM.

Arık, Ruçhan (1978), "Turkish Landscape Carpets", Halı, I, No 2, London, s.122-127.

Arık, Ruçhan (1983), “Manzaralı Halılar”, II. Milletlerarası Türk Folklor Kogresi Bildirileri, C. V, s. 23-30.

Aslanapa, Oktay- Yusuf, Durul, Selçuklu Halıları, Ak Yayınları, Akbank.

Aslanapa, Oktay (1987), Türk Halı Sanatının Bin Yill, Eren.

Aslanapa, Oktay (1997), "Türk Halı Sanatının Tarihi Gelişmesi", Arıs, Başbakanlık Atatürk Kültür Dil ve Tarih Yüksek Kurumu, Atatürk Kültür Merkezi, S.3, s.18-25.

Aslanapa, Oktay (1997), " Türk Halı Sanatında Yeni Keşifler", Arış, Başbakanlık Atatürk Kültür Dil ve Tarih Yüksek Kurumu, Atatürk Kültür Merkezi, S.2, s.10-17.

Atalay, Besim (1967), Türk Halıcllğı Ve Uşak Halıları, Türkiye İş Bankası.

Aytaç, Ahmet (2003), Hotaliş Türkmen Kilimleri, Konya Valiliği, Kültür ve Turizm Müdürlüğü, Konya

Aytaç, Ahmet (2009), Yukarıçiğil Kilimleri, Yukarıçiğril Belediyesi, Konya

Uluslar arası Eşme Kilim Festivali Türkiye Kilimciliğinin Üretimve Pazarlama Sorunları Sempozyumu (1995), Turizm Geliştirme Vakfı, Ankara.

Aytaç, Çetin (1982), El Dokumacilı̆̆, Devlet Kitapları, İstanbul: Milli Eğitim Basımevi.

Bakırcı, Naci (1997)," Mevlana Müzesi Halı Kumaş Seksiyonunda Sergilenen Türk Halıları", Arıss, Başbakanlık Atatürk Kültür Dil ve Tarih Yüksek Kurumu, Atatürk Kültür Merkezi, S.1, s.120-133.

Bannon, George, O. (1991), “ Anatolian Kilim's In Sanfrancisco", Oriental Rug Review, V. XII, N.1, s.32.

Barışta, H. Örcün (1982), “Divan-1 Lügat-it Türk'de Dokuma ve Dokumanın Üzerine Yapılan Bezemeler Çevresinde Kümelenen İfadeler", 2.Ulusal El Sanatları Sempozyumu Bildirileri, İzmir: Dokuz Eylül Üniversitesi Güzel Sanatlar Fakültesi Yayınları, s. 32-39.

Barışta, H. Örcün (1985), Turkish Handicrafts, Expo 85 Yayınları, Ankara: Türk Tarih Kurumu Matbaası; Barışta, H.Örcün, Turkish Handicrafts, Ministry of Culture And Tourism Publications: 974, Art Book Series: 11, (Expo 85 için hazırlanan genişletilmiş baskısı); Barışta, H.Örcün (1988), Türk El Sanatları, Ankara: Kültür ve Turizm Bakanlığı Yayınları, 975, Sanat Eserler Dizisi, 11, (Yukarıdaki Kitabın Türkçesi); Barışta, H.Örcün (1998), Türk El Sanatları, Genişletilmiş íkinci Baskı, Ankara: Kültür Bakanlığı Yayınları: 2168, Sanat Eserleri Dizisi: 192

Barışta, H. Örcün (1989), "Selçuklu Dönemi Tekstil Sanatı Üzerine", Antalya 3. Selçuklu Semineri Bildiriler, İstanbul: Antalya Valiliği Yayınları, s. 18-31

Barışta, H. Örcün (1992), "Karaman Taşkale Dokumacılığı”, Türk Halk Kültürü Araştırmaları, Kültür Bakanlığı, Ankara: Halk Kültürlerini Geliştirme Genel Müdürlüğü Yayınları 171, s.1-12

Barışta, H. Örcün (1994), "Isparta Halıcılığı Üzerine”, Kamu ve Özel Kuruluşlarla Orta Ögrretim ve Üniversitelerde El
Sanatlarına Yaklaşım ve Sorunları Sempozyumu Bildirileri, Kültür Bakanlığı, Halk Kültürlerini Araştırma Geliştirme Genel Müdürlüğü,- Dokuz Eylül Üniversitesi Rektörlüğü, Ankara, s. 53-66.

Barışta, H. Örcün (1995), “19. Yüzyıla Ait Türk Halılarından Nevşehir'de Bulunan Beş Örnek", IX. Milletlerarası Türk Sanatları Kongresi, Ankara, C.I, S. 265-273.

Barışta, H. Örcün (1995), “Sarayönü ve Ladik'te Bulunan Türk Halılarından Bazı Örnekler", Vakıflar Dergisi, N. XXV, s. 211-234.

Barışta. H. Örcün (1997), "Konya Yükselen Eski Bilecikten Bazı Halı Örnekleri", El Sanatları Dergisi, Selçuk Üniversitesi, Türk El Sanatlarını Araştırma ve Uygulama Merkezi, N. I, s.99-112.

Barışta, H. Örcün (1997), "Bir Müzayede Sergisinden Sağlanan Bilimsel Katkıya Bir Örnek Uçaklı Halı", Kuruluşunun 150. Yllinda Türk Müzeciliği Sempozyumu, Genelkurmay Askeri Tarih ve Stratejik Etüd Dairesi Başkanlığı Yayınları, Ankara: Genel Kurmay Basımevi, s. 138-142.

Barışta, H. Örcün (1997), “Türk Dünyası El Sanatları Üzerine”, Türk Dünyası Özel Sayısı I, Yeni Türkiye, s. 617-630.

Barışta, H. Örcün (1998), "19-20. Yüzyıl İç Anadolu ve Orta Akdeniz Bölgesi Türk Kirkitli Dokumaları Üzerine", Türk Soylu Halkların Halı,Kilim, ve Cicim Sanatı Uluslararası Bilgi Şöleni Bildirileri, Atatürk Kültür Merkezi Başkanlığı Yayınları, s.39-56

Barışta, H. Örcün (1999), "Karaman Taşkale Halılarından Örnekler", Erdem, Halı Özel Sayısı I, Atatürk Kültür Dil ve Tarih Yüksek Kurumu, S:28, C.10, s.34-48, 173-184.

Barışta, H. Örcün, "Emirdağ ve Çevresinin Kirkitli Dokumaları", Sanatsal Mozaik, N.18, s.22-25

Barışta, H. Örcün (2000), “Konya'nın Osmanlı İmparatorluğu Dönemi El Sanatları", Uluslararası Kuruluşunun 700. Yıl Dönümünde Bütün Yönleriyle Osmanlı Devleti Kongresi, Selçuk Üniversitesi, Konya, s. 845-854.

Barışta, H. Örcün (2000), "Hakkari El Sanatları Sergisinin Ardından-Dünden Bugüne Hakkariden Bazı Tekstil Ürünleri“, Dağların Kenti Hakkari, S. 17, s. 3-6.

Barışta, H. Örcün (2001), “Örcün Köyü Tekstil Sanatları Üzerine“, Dünden Bugüne Karaisal, Kuvayı Milliye Şenlikleri Konferanslar Dizisi, Adana Karaisali, s. 91-102.

Barışta, H. Örcün (2001), "Osmanlı İmparatorluğu Dönemi Halıları ve İşlemeleri Arasındaki Benzerlikler", Prof. Dr.Zafer Bayburtluoğlu Armağanı, Sanat Yazıları, Kayseri, s. 65-71

Barışta, H. Örcün (2004), “Cumhuriyet Döneminin Ankara’ya Armağanlarından Ankara Beypazarı Kültür ve Sanat Müzesi Halıları Üzerine", Cumhuriyetin 80. Yilında Her Yönüyle Ankara, Gazi Üniversitesi- Ankara Büyükşehir Belediyesi, s. 201-206- Fotoğraflar 351-357.

Barışta, H. Örcün (2005), Türkiye Cumhuriyeti Dönemi Halk Plastik Sanatları, Ankara: Kültür ve Turizm Bakanlı̆̆ı.

Barışta, H. Örcün (2005), "Bazı Gözlemler Işığında Göçer Çadırları", VIII. Ortaçağ ve Türk Dönemi Kazıları ve Sanat Tarihi Araştırmaları Sempozyumu, Sakarya Üniversitesi, Fen Edebiyat Dergisi, C. 7, S. 1, s. 36-50.

Barışta, H. Örcün (2005), "Halı Sanatının Bazı Azeri, Türkmen, Kırgız ve Kazak Örnekleriyle Benzerliklerine Dair", 3. Internatioal Symposium Azerbaijan Carpet And Traditional Applied Arts, Ministry of Culture of the Repurblic of Azarbaijan, Baku-Elm, 102-107.

Barışta, H. Örcün (2009), “Türk Tekstil Sanatlarını Süsleyen Konulardan Bazı Motifler", Türk Dünyası Araştırmaları, 
Prof.Dr.Oktay Aslanapa Özel Sayısı,Türk Dünyası Araştırmaları Vakfı, S.183, s. 25-46.

Barışta, H. Örcün (2009), "Konya Müzelerinde Bulunan Geç Dönem Halıları Üzerine" II.Uluslararası Türk El Dokumaları (Tekstil) Kongresi ve Sanat Etkinlikleri, Selçuk Üniversitesi, Selçuklu Araştırma Merkezi Başkanlığı, Konya.

Batari, Ferenc (1986), Five Hundred Years In The Art Of Ottoman Carpet Making, The Museum Of Applied Art, Budapest.

Bayraktar, Suzan (1997), "Vakıflar Genel Müdürlüğü Halı ve Kilim Koleksiyonu", Arıs, Başbakanlık Atatürk Kültür Dil ve Tarih Yüksek Kurumu Atatürk Kültür Merkezi, S. 2, s. 88-103.

Bayraktar, Suzan.- Özçelik, Serpil (2007), Halı Müzesi İle Kilim Ve Düz Dokuma Yaygllar Müzesi Kataloğu, T.C. Vakıflar Genel Müdürlüğü, Ankara.

Bodur, A. Fulya (1984), "Batı Anadolu Uşak Halıları" Türk Edebiyatı, S.132, s.33-34.

Bodur, A. Fulya (1988), Halıcılık Tarihine Kısa Bir Bakış ve Konya Halıları, Vakıflar Dergisi, Vakıflar Genel Müdürlüğü, S.XX, s.105-114.

Çirtil, Saim (1991), Kayseri Müzesi'ndeki Halı Ve Kilimler, Selçuk Üniversitesi Sosyal Bilimler Enistitisü, Arkeoloji Sanat Tarihi Anabilim Dalı, Sanat Tarihi Bilim Dalı Konya, (Yayımlanmamıș Yüksek Lisans Tezi)

Deniz, Bekir (1982), “Taşpınar Halıları”, Sanat Dünyamı, Yapı ve Kredi Bankası, S. 25, s. 18-22.

Deniz, Bekir (1984), “Aksaray Müzesi Halıları”, III. Ulusal El Sanatlar Sempozyum Bildirileri, 23- 25 Kasım 1983 - İzmir, s. 112-119.

Deniz, Bekir (1985), "Kula Halıları", Bilim, Birlik, Başarı, S.43, s. 13-19.

Deniz, Bekir (1986), "Gördes Halıları" Bilim, Birlik, Başarı, S. 45, s. 13-19.

Deniz, Bekir (1986), "Ladik Halıları”, Bilim, Birlik, Başarı, S.46, s. 13-18.

Deniz, Bekir (1986), "Kırşehir Halıları" Bilim, Birlik, Başarı, S. 47, s. 18-24.

Deniz, Bekir (1987), "Mucur Halıları", Bilim, Birlik, Başarı, S.48, s.20-24.

Deniz, Bekir (1987), “ Milas Halıları”, Bilim, Birlik, Başarı, S. 49, s. 13-20

Deniz, Bekir (1987), "Arısama Halıları", Lale, S. 5, s. 9-15.

Deniz, Bekir (1990), "Yöre Özellikleriyle Yozgat Kilimleri", Arkeoloji ve Sanat Tarihi Dergisi, İzmir: Ege Üniversitesi Edebiyat Fakültesi Yayını, s.69-84.

Deniz, Bekir (1992), "Yunddă̆ Yöresi Kilim ve Düz Dokuma Yaygıları", IV Milletlerarası Türk Halk Kültürü Kongresi, Ankara, Maddi Kültür, C.5, s. 69-84

Deniz, Bekir (1995), "Yöre Özellikleriyle Yunddağ Halıları", Dokuzuncu Milletlerarası Türk Sanatları Kongresi, Ankara, s. 33-46.

Deniz, Bekir (1997), "Kozak Bergama Yöresi Halıları", Arış, Başbakanlık Atatürk Kültür Dil ve Tarih Yüksek Kurumu, Atatürk Kültür Merkezi, N.2, s.18-37.

Deniz, Bekir (1998), “ Geçmişten Günümüze Aksaray Halıları, Arış, Başbakanlık Atatürk Kültür Dil ve Tarih Yüksek Kurumu, Atatürk Kültür Merkezi, s. 90-103.

Deniz, Bekir (1998), Ayvacık Çanakkale Yöresi Düz Dokuma Yaygıları, Başbakanlık Atatürk Kültür Dil ve Tarih Yüksek Kurumu, Atatürk Kültür Merkezi, Ankara.

Deniz, Bekir (1999), Osmanlı Dönemi Halıları", Osmanlı Kültür ve Sanat, Ed.G. Eren, Ankara: Yeni Türkiye Yayınları, C. 11, s. 381-394.
Deniz, Bekir (1999), Osmanlı Dönemi Kilimleri”, Osmanlı Kültür ve Sanat, Ed.G. Eren, Ankara: Yeni Türkiye Yayınları, C.11, s.381-394

Deniz, Bekir (2000), Türk Dünyasında Halı ve Düz Dokuma Yaygılar, Başbakanlık Atatürk Kültür Dil ve Tarih Yüksek Kurumu, Atatürk Kültür Merkezi

Deniz, Bekir (2008), "Gazi Paşa (Antalya Yöresi Kirkitli Dokumaları", GSEI, Güzel Sanatlar Etkinlikleri Bildiriler, Antalya, s. 113-101.

Diez, Ernst- Aslanapa, Oktay, Türk Sanatı, İstanbul Üniversitesi Edebiyat Fakültesi Yayınları, No 627, İstanbul.

Dirik, Kazım (1938), Eski ve Yeni Türk Halıcilı̆ı, İstanbul.

Durul, Yusuf (1977), Yörük Kilimleri, Akbank, Süsleme Sanatları: 6, İstanbul.

Durul, Yusuf (1985), Anadolu Kilimlerinden Örnekler, Akbank.

Durul, Yusuf (1987), Anadolu Kilimlerinden Örnekler, Akbank.

El Dokuması Hallar (Turkish Handwoven Carpets), Kültür ve Turizm Bakanlığı, Katalog 1; Katalog 2; katalog 3; Katalog 4, Katalog 5 Güran Erbek Anısına, (In the Memory of Güran Erbek)

Erdmann, Kurt (1976), Oriental Carpets, The Crosby Press, s. 17-23, 23-29, 47-56.

Erdmann, Kurt, Der Türkishe Teppische Des 15. Jahrhunderts-15. Yüzyıl Türk Halısı, İstanbul Edebiyat Fakültesi Yayınları: 715, Maarif Basımevi, Türkçe Metnin Redaksiyonu S. Ögel.

Eyüpoğlu, Öner - Okaygün, Itır- Yaraş, Fusun (1983), Doğal Boyalarla Yün Boyama Uygulamalı ve Geleneksel Yöntemler, Uygulama, A.Ş., İstanbul.

Fazlığlu, Ayşe (2007), Düğümün Son Halkası; Osmanlı Sarayı Halları (Last Loop of The Knot; Ottoman Palace Carpets, Translition: Çiğdem Aksoy Fromm, TBMM, Milli Saraylar.

Fransis, Micheal (2007), “Transilvanya Kiliselerindeki Osmanlı Halıları, Katalog", Tanrı 'ya Atanmış Halılar Transilvanya Kiliselerinde Anadolu Halıları 1500-1750, Sakıp Sabancı Müzesi.

Görgünay, Neriman (1983), "Bardız Kilimleri”, II.Milletlerarası Türk Folklor Kongresi, V.5, Maddi Kültür, Ankara: Başbakanlık Basımevi, s. 89-101.

Görgünay, Neriman (1994), Eşme Kilimleri, Başbakanlık Atatürk Kültür Dil ve Tarih Yüksek Kurumu, Atatürk Kültür Merkezi, Ankara.

Güçlü, Adnan, "Emirdağ Yöresi Kilimlerinden Örnekler,"Emirdağ Kültür Araştırmaları Sempozyumu, Téliğler, 1-3 Haziran 1995, Emirdağ Kaynakamlığı, Eskişehir.

Hakkari Kilimleri (1997), Hakkari Valiliği, Ankara.

Karadağ, Recep (1997), "Doğal Boyar Maddeler”,Arıs, Başbakanlık Atatürk Kültür Dil ve Tarih Yüksek Kurumu Atatürk Kültür Merkezi, S.2, s. 38-51

Karadağ, Recep (2007), Doğal Boyamacilı, Kültür ve Turizm Bakanlığı.

Karahan, Recai (1992), Konya Müzelerinde Bulanan Kilimler, Selçuk Üniversitesi Sosyal Bilimler Enistitisü, Arkeoloji Sanat Tarihi Anabilim Dalı, Sanat Tarihi Bilim Dalı, Konya. (Yayımlanmamış Doktora Tezi)

Karahan, Recai (2007), Dünden Bugüne Hakkari Kilimleri, Kültür ve Turizm Bakanlığı, Ankara.

Kayıpmaz, Fahrettin - Kayıpmaz, Naciye - Genç, Mustafa (2001), Tarihten Günümüze Bergam Halları, Bergama Belleten 10, Bergama Kültür ve Sanat Vakfı.

Karoly, Gombos, Regi Kelleti Szönyegek Altorientalische TeppicheOld Oriental Rugs, Kereszteny Museum Esztergom 1977, Christliches Museum Zu Esztergom Hungary 
1977. Christian Museum In Estergom Hungary, 1977

Kilimlerimiz (2000), Balıkesir Valiliğgi, Balıkesir.

Kotan, Vasfi (1949), Türkiye'de Halıcllk, İstanbul Ticaret ve Sanayi Odası, İstanbul.

Koç, Sema (1998), “Ankara Etnografya Müzesi Halı Kilim Koleksiyonu", Arış, Başbakanlık Atatürk Kültür Dil ve Tarih Yüksek Kurumu, Atatürk Kültür Merkezi,s. 104-113.

Kuşhan, Gülhan (1986), Bardız Kilimleri, Gazi Üniversitesi, Sosyal Bilimler Enistitüsü, Ankara, (Yayımlanmamış Yüksek Lisans Tezi)

Küçükerman, Önder (1987), Hereke Fabrikası, Sümerbank, İstanbul.

Küçükerman, Önder (1990), Batı Anadolu'daki Türk Halıcllk Geleneği İçinde İmir Limanı ve Isparta Halı Fabrikası, Sümer Halı, Ankara.

Mallett, Marla (1991), "The Classification of Anatolian Brocades", Oriental Rug Review, V.XII, N.1, Oct./Nov. ,p.17.

Nekrasova, N.P. - Kınayeva, K.G. (1997), Moskova Şark Sanatlarl Devlet Müzesi Türk Azeri Ve Türkmen Seccadeleri, Çev. Cem Oğuz, Atatürk Kültür Merkezi, Ankara.

Onuk, Taciser - Akpınarlı, Feriha - Ortaç, H. Serpil - Özlem, Alp (1998), Tarsus El sanatları, Kültür Bakanlığı, Ankara

Onuk, Taciser - Akpınarlı, Feriha (2003), Şanlıurfa Karakeçili Kilimleri, Başbakanlık Atatürk Kültür Dil ve Tarih Yüksek Kurumu, Atatürk Kültür Merkezi.

Ölçer, Nazan (1988), Türk İslam Eserleri Müzesi Kilimler, İstanbul: Eren Yayıncılık.

Ölçer, Nazan - Volkman, Enderlein - Batari, Frenc - Mills, John - Ruters, Nils (1996), Turkish Carpet From The 13th18th Centuries, Textilbank, Ertuğ.

Öney, Gönül - Erginsoy, Ülker (1978), Anadolu Mimarisinde Süsleme ve El Sanatları, Ankara: Türkiye İş Bankası Kültür Yayınları, Genel Yayın No:185, Sanat Dizisi:33, s. 125-132.

Öney, Gönül (1989), Beylikler Devri Sanatı, XIV-XV. Yüzyıl, 1300-1453, Atatürk Kültür, Dil Ve Tarih Yüksek Kurumu, Ankara, s. 51-54.

Özbel, Kenan, Kılavuz Kitaplar, Cicim ve Sili, El Sanatları VII, C.H.P Halkevleri Bürosu.

Özbel, Kenan, Kılavuz Kitaplar, Anadolu Kilimleri, El Sanatları IX, C.H.P Halkevleri Bürosu.

Öztürk, Yeşim (1992), Balıkesir Sindıgı Yöresi Yağcıbedir Halıla$r$, Kültür Bakanlığı, Ankara. Öztürk, İsmail - Gonca Karavar (1997), Türk Halı Kilim Biblioğrafyası, Arış, Başbakanlık Atatürk Kültür Dil ve Tarih Yüksek Kurumu Atatürk Kültür Merkezi, S.I, s. 154-157.

Öztürk, İsmail - Gonca Karavar (1997), Türk Halı Kilim Biblioğrafyası II, Arıs, Başbakanlık Atatürk Kültür Dil ve Tarih Yüksek Kurumu Atatürk Kültür Merkezi, S.2, s.76-89.

Öztürk, İsmail - Gonca Karavar (1997), Türk Halı Kilim Biblioğrafyası III, Arış, Başbakanlık Atatürk Kültür Dil ve Tarih Yüksek Kurumu Atatürk Kültür Merkezi, S.3. s. 116-121.

Öztürk, İsmail - Gonca Karavar (1998), “Türk Halı Kilim Biblioğrafyası”, IV, Arış, Başbakanlık Atatürk Kültür Dil ve Tarih Yüksek Kurumu, Atatürk Kültür Merkezi, S. 4, s. 120-122.

Öztürk, İsmail, Doğal Bitkisel Boyalarla Yün Boyama Ürün Yayınları: 15, Temel Kaynak Dizisi 04.
Pektaş, Hafize (1992), Karapınar Ev Ve Camilerinde Bulunan Kilimler, Selçuk Üniversitesi, Sosyal Bilimler Enistitüsü, El Sanatları Anabilim Dalı, Konya. (Yayımlanmamış Yüksek Lisans Tezi)

Seyirci, Musa (1992), “Antalya'daki Karakoyunlu Aşireti ve Dokumaları", IV. Milletlerarası Türk Halk Kültürü Kongresi Bildirileri, Halk Kültürlerini Araştırma ve Geliştirme Genel Müdürlüğü, Ankara, s. 183-191

Tapan, Nazan (1983), Hicretin 15. Yüzyllinda İlam Sanatları Sergisi,islamda Halı Sanatı- On The Occasion Of The Fifteenth Centennial of Hegira Islamic Art Exhibition-Carpets In İslam, Ministry Of Culture And Tourism, İstanbul.

Tazecan, Hakan (1991), Saf Kilim ve Seccadeler Üzerine Bir Deneme, Selçuk Üniversitesi Sosyal Bilimler Enistitisü, Sanat Tarihi Anabilim Dalı, Konya. (Yayımlanmamış Yüksek Lisans Tezi)

Togay, Fatih (1987), 16-17-18. Yüzyıllara Ait Uşak Halılarının Istanbul Türk ve İslam Eserleri Müzesi, İstanbul Vakiflar Halı Müzesi Ve Edirne Müzesi'ndeki Örnekleri, Gazi Üniversitesi, Sosyal Bilimler Enistitüsü, Ankara, (Yayımlanmamış Yüksek Lisans Tezi)

Topbaş, Ahmet (1994), "Afyonkarahisar ve Yöresi Kilimleri", Kültür ve Sanat, Türkiye İş Bankası Yayınları, S. 21, s. 54-55.

Türk ve İslam Eserleri Müzesi (2002), Akbank, s. 276-279, 310313.

Türkmen, Nalan (2001), Orta Asya Türkmen Halıları Mle Tarihi Anadolu - Türk Halılarının Ortak Özellikleri, Başbakanlık Atatürk Kültür Dil ve Tarih Yüksek Kurumu Atatürk Kültür Merkezi, Ankara

Uçan, Serap (2000), Vakıflar Genel Müdürlüğ̈̈ Halı Ve Kilim Sergisinde Sergilenen Anadolu Kaynaklı Halılar, Gazi Üniversitesi, Fen Edebiyat Fakültesi Sanat Tarihi Bölümü Sanat Tarihi Anabilim Dalı, Ankara. (Yayımlanmamış Lisans Tezi)

Ürer, Harun (1997), Emirdağ (Afyon) Yöresi Düz Dokuma Yaygılar, E.Ü.Sosyal Bilimler Enistitüsü, Türk ve İslam Sanatı Anabilim Dalı, İzmir, (Yayınlanmamış Yüksek Lisans Tezi)

Ürer, Harun (2002), Yabancı Şirketlerin Batı Anadolu Bölgesi'ndeki Haliclik Faaliyetler Ve Bunun Geleneksel Türk Halı Sanatına Etkileri, Ege Üniversitesi, Sosyal Bilimler Enistitüsü, Sanat Tarihi Ana Bilim Dalı, İzmir. (Yayımlanmamış Doktora Tezi)

Ürer, Harun (2007), Haneden Ticarethaneye Batı Anadolu Halıcılığı (1836-1935) İzmir: Ege Üniversitesi Yayınları, Edebiyat Fakültesi Yayın No:139.

Van Kilims (1998), Van Valiliği, Ankara

Yetkin, Şarare, "Divriği Ulu Camide Bulunan Osmanlı Saray Üslubundaki Kilimler", Belleten, V. XLII, s. 165.

Yetkin, Şerare (1991), Türk Halı Sanatı, Türkiye İş Bankası, Ankara.

Yetkin, Şerare (1972-1973), “Yeni Bulunan Hayvan Figürlü Halıların Türk Halı Sanatında Yeri", Sanat Tarihi Yıllı̆̆ı, İstanbul Üniversitesi Edebiyat Fakültesi, Sanat Tarihi Enstitüsü, V. 5, s. 145, 146

Yetkin, Şerare (1993), "Türk Halı Sanatı", Başlangııından Bugüne Türk Halı Sanatı, Türkiye İş Bankası, s.311-342. 
Atatürk Kültür Merkezi

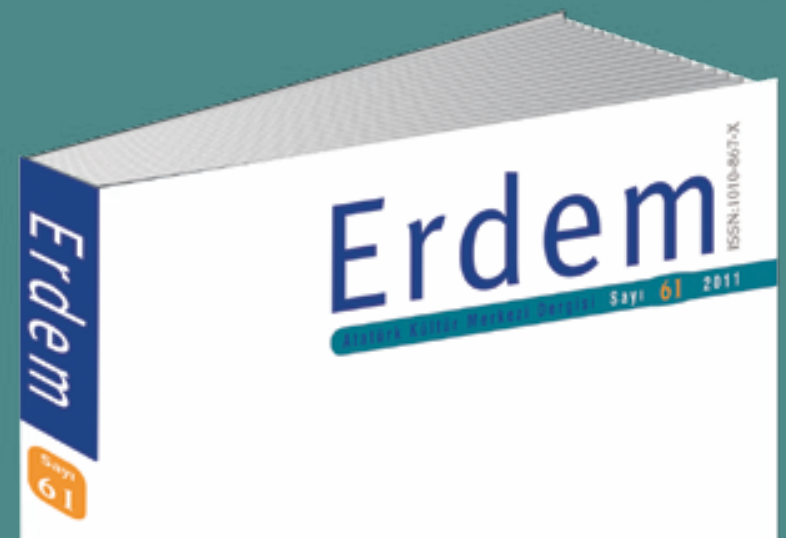

\section{ERDEM Dergisi... \\ süreli yayını}

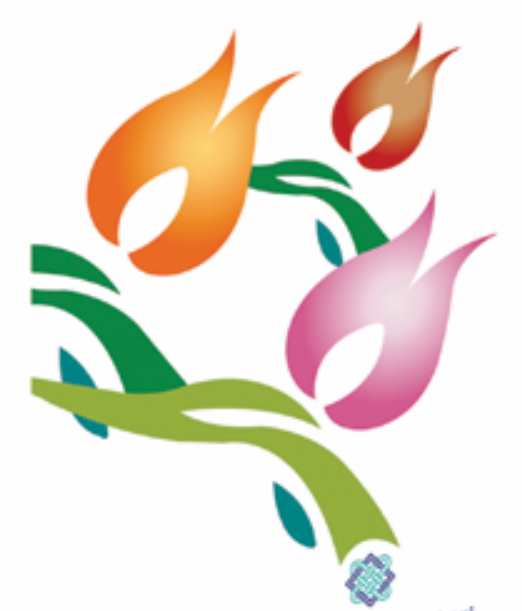

eAtatûrk Küttūr Merkezi

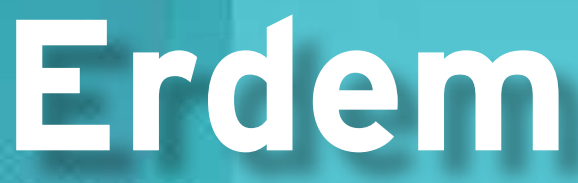

Atatürk Kültür Merkezi

Dergisi

T.G. BAŞBAKANLIK

ATATÜRK KÜLTÜR, DIL VE TARIH YÜKSEK KURUMU ATATÜRK KULUR MERKEZI

www.akmb.gov.tr http://e-magaza.akmb.gov.tr 